\title{
Growth performance and haematological traits of Nigerian local chickens fed varied dietary protein levels
}

Oleforuh-Okoleh, V. U., Nte, I. J. and Onyegbule, Q.

Department of Animal Science, Rivers State University of Science and Technology, Nkpolu-Oroworokwu, P.M.B. 5080, Port Harcourt. Corresponding author e-mail: vivoleh@gmail.com

\begin{abstract}
This study was carried out to investigate the growth performance and haematological traits of Nigerian local chickens (NLC) fed varied dietary protein levels. An eleven week feeding trial was done in a $3 \times 2$ factorial arrangement using six treatment groups comprising a combination of two genotypes of the NLC identified as normal feather (na) and naked neck $\mathrm{Na}$ ) and three dietary protein levels - high protein: HP (22\% and 20\% CP chick mash and grower mash respectively), medium protein: $M P(20 \%$ and $18 \%$ chick mash and grower mash respectively) and low protein: LP (18\% and $16 \%$ chick mash and grower mash). Data were collected on growth performance traits (body weight, feed intake, feed conversion ratio and protein efficiency ratio). At the end of the feeding trial a haematological assay was done. Neither genotype nor interaction of genotype and dietary protein level influenced ( $p>0.05)$ any of the growth performance traits studied. Birds on HP ate $10.21 \%$ and $7.09 \%$ less feed than those on MP and LP respectively. A better $(p<0.05$ ) protein efficiency ratio (up to $20.79 \%$ ) was observed in birds fed LP. Na birds had $4.55 \%$ and $17.50 \times 10^{3} \mathrm{~L}^{-1}$ more packed cell volume and platelets respectively than na birds $(p<0.05)$. All haematological traits studied, except white blood cell count, showed significant variations $(p<0.05)$ due to varied dietary protein levels. Higher haemoglobin, red blood cell counts, mean corpuscular haemoglobin concentration and platelets were observed in birds fed LP diet. Reducing the dietary protein level had no adverse effect on the NLC thus, the LP diet is recommended for raising the Nigerian local chicken.
\end{abstract}

Keywords: dietary protein, growth performance, local chicken, haematology, naked neck, normal feather

\section{Introduction}

The Nigerian local chickens are rich animal genetic resource and are widely distributed in the country. They are generally hardy and possess good adaptive traits, contributing significantly to human livelihood and food security (Ndofor-Foleng et al., 2015). Over the past few decades, there have been increased concerns towards improvement and conservation of the local chicken (Nwosu, 1979; Nwosu and Omeje, 1985; Adebambo, 2005; Oleforuh-Okoleh et al., 2012; Udeh et al., 2013). Incidentally, their genetic potentials have not been fully harnessed in order to incorporate them into large scale poultry production (Oleforuh-
Okoleh, 2013). Mugga (2007) attributed the non-integration of the local chicken into commercial poultry production to the slow growing nature of the birds.

Growth is an essential yardstick in measuring the performance of chickens and depends not only on the growth hormone but also on other factors which could be genetic, environmental or an interaction of both. The poultry breeder during the process of selection aims at genetic improvement to produce birds which are larger at a given age and show greater potentials than their ancestors. The genetic potential of an animal however, can only be fully manifested under a favourable 
environment. One major problem associated with efficient management of local chickens is feeding. Most often, they are raised extensively with little or no supplementation with formulated diets. Bearing in mind that the speed of growth of this class of chickens will depend, among other factors, on its plane of nutrition, it becomes imperative that the nutritional status is improved.

Genetically, chickens have predetermined nutrient requirement and usually consume feed to meet this requirement; of much relevance is the protein requirement. Liu et al. (2015) noted that protein is an essential nutrient required for the process of life. Harper and Rogers (1965) from their study asserted that protein deficiency tends to reduce growth and feed efficiency. Unlike the commercial chicken strains whose nutrient requirements have been studied and documented (Wethl and Morris, 1978; Havenstein et al., 1994; NRC, 1994; Neto et al., 2000), there is dearth of such information with respect to local chickens. The works of Chemjor (1998) and Magala et al. (2012) with local chickens of Kenya and Uganda respectively showed that variations in the dietary protein influenced the performance of intensively raised chickens. This led us to hypothesize that there could also be a variation in the dietary protein requirements of the Nigerian local chicken. Taking into cognizance that any component (feed or otherwise) ingested by an animal has a measureable effect on its blood composition, studies of haematological traits have become crucial measures for not only feed stress monitoring but also disease diagnosis and curative therapy(Olabanji et al., 2007; Togun et al.,2007). This study was therefore intended to compare the effect of three dietary protein levels on the growth performance and hematological traits of Nigerian local chickens.

\section{Materials and Methods Study site}

The experiment was carried out at the Poultry Unit of the Department of Animal Science, Rivers State University of Science and Technology (RSUST), NkpoluOroworukwo, Port Harcourt, Rivers State, Nigeria. The average annual rainfall in Port Harcourt is $200.45 \mathrm{~mm}$ with average monthly temperature and relative humidity of $22.54-31.03^{\circ} \mathrm{C}$ and $69.08-112.47 \%$ respectively. (Uko and TamunoberetonAri, 2013).

Experimental design and treatments

126 day-old improved Nigerian local chicks (NLC) of two genotypes were used for the study. The local chicks originated from a population of NLC under limited selection (about eight generations) for growth at the Poultry Breeding Unit, Federal University of Agriculture, Abeokuta, Nigeria. They were brooded and allowed to acclimatise for 7 days on dietary crude protein of $20 \%$ before the feeding trial which lasted eleven weeks commenced. Six treatment groups consisting of two genotypes of the NLC designated $\mathrm{na}$ (normal feather) and $\mathrm{Na}$ (naked neck) and three isocaloric diets but varied dietary protein levels were used. The diets were identified as HP (high crude protein), MP (medium crude protein) and LP (low crude protein) - formulated such that from 1-8weeks, the birds were fed diets consisting of 22,20 and $18 \%$ crude protein (CP) respectively and from $8-12$ weeks 20 , 18 and $16 \%$ crude protein (CP) respectively. Each treatment group was replicated three times with seven birds per replicate. Gross and determined compositions of the diets are presented in Table 1. The crude protein and energy analysis were done according to the methods of AOAC (2010). The birds had access to fresh water ad-libitum throughout 


\section{Oleforuh-Okoleh, Nte and Onyegbule}

the study period. Birds in all treatment groups received similar standard routine management practices. They were vaccinated against the following diseases Newcastle (intra-ocular and lasota), gumboro and fowl pox as per routine vaccination schedule.

Table 1: Gross and determined composition of diets

\begin{tabular}{|c|c|c|c|c|c|c|}
\hline \multirow[t]{2}{*}{ Feed type } & \multicolumn{3}{|c|}{ Chick mash } & \multicolumn{3}{|c|}{ Growers mash } \\
\hline & HP & MP & & HP & MP & \\
\hline$\% \mathrm{CP}$ & 22 & 20 & 18 & 20 & 18 & 16 \\
\hline \multicolumn{7}{|l|}{ Ingredient (kg) } \\
\hline Maize & 53.00 & 54.35 & 55.70 & 41.70 & 43.05 & 44.40 \\
\hline Soybean meal & 32.00 & 25.00 & 18.00 & 23.50 & 16.50 & 9.50 \\
\hline Palm kernel cake & 5.00 & 8.30 & 11.60 & 20.00 & 23.30 & 26.60 \\
\hline Wheat bran & 2.65 & 5.00 & 7.35 & 10.00 & 12.35 & 14.70 \\
\hline Fish meal & 2.50 & 2.50 & 2.50 & 0.00 & 0.00 & 0.00 \\
\hline Bone meal & 3.00 & 3.00 & 3.00 & 3.00 & 3.00 & 3.00 \\
\hline Limestone & 1.00 & 1.00 & 1.00 & 1.00 & 1.00 & 1.00 \\
\hline Salt & 0.35 & 0.35 & 0.35 & 0.35 & 0.35 & 0.35 \\
\hline Lysine & 0.10 & 0.10 & 0.10 & 0.10 & 0.10 & 0.10 \\
\hline DL-Methionine & 0.15 & 0.15 & 0.15 & 0.10 & 0.10 & 0.10 \\
\hline Premix & 0.25 & 0.25 & 0.25 & 0.25 & 0.25 & 0.25 \\
\hline Total & 100.00 & 100.00 & 100.00 & 100.00 & 100.00 & 100.00 \\
\hline \multicolumn{7}{|l|}{ Protein and Energy Composition } \\
\hline Crude Protein $(\%)$ & 22.10 & 20.10 & 18.20 & 20.04 & 18.07 & 16.09 \\
\hline Metabolizable energy $\left(\mathrm{Kcal} \mathrm{kg}^{-1}\right)$ & 2804.00 & 2804.00 & 2804.00 & 2604.60 & 2604.60 & 2604.30 \\
\hline
\end{tabular}

\section{Data collection}

Birds were weighed on commencement of the feeding trial and weekly thereafter up to the 12th week of age (11 weeks of feeding trial). From this, the average daily body weight gain (ADG) was estimated. Measured quantity of feed was given to the birds on a daily basis and this was used to obtain the average daily feed intake (ADFI) at the end of the feeding trial. The ratio of ADFI to ADG was used to calculate feed conversion ratio (FCR) and the protein efficiency ratio (PER) obtained using the ratio of gain in body weight to protein consumed. At the end of the feeding trial, haematological assay of the birds was carried out. To achieve this, three birds were picked at random from each replicate per treatment group. Blood samples were drawn from the right jugular vein of each of them using sterile syringe after swabbing with methylated spirit. The blood was quickly discharged into bottles containing an anticoagulant EDTA (ethylene diamine- tetraacetic acid). The samples were used to perform the following haematological analysis: red blood cell (RBC) count using the improved neubauer ruled chamber; haemoglobin concentration $(\mathrm{Hb})$ - using the cyanmethaemoglobin method; white blood cell (WBC) counts and packed cell volume (PCV) using the microhaematocrit method. The procedure outlined in Feldman et al. (2000) was applied. Red blood indices which include mean corpuscular volume (MCV), mean corpuscular haemoglobin $(\mathrm{MCH})$ and mean corpuscular haemoglobin concentration (MCHC) were calculated using the formula of Bull and Hay (2001).

\section{Statistical Analysis}

The study was a $3 \times 2$ factorial in Completely Randomized Design (CRD). The analysis of variance (ANOVA) for all data was done using multivariate analysis in General Linear Model (GLM) procedure of SPSS (2010). Significant means were separated using Duncan. The following 
model was adopted:

$\mathrm{X}_{\mathrm{ijk}}=\mu+\mathrm{D}_{\mathrm{i}}+\mathrm{G}_{\mathrm{j}}+\mathrm{DG}_{\mathrm{ij}}+\mathrm{E}_{\mathrm{ijk}}$

Where

$X_{\mathrm{i} j \mathrm{k}}=$ the analysed measurement

$=$ overall mean

$\mathrm{D}_{\mathrm{i}}=$ effect of $\mathrm{D}_{\mathrm{th}}$-dietary protein level $(\mathrm{i}=$

$1,2,3)$

$\mathrm{G}_{\mathrm{j}}=$ effect of $\mathrm{G}_{\mathrm{th}}$ genotype $(\mathrm{j}=1,2)$

$\mathrm{DG}_{\mathrm{ij}}=$ Interaction of the $\mathrm{D}_{\mathrm{th}}$ dietary protein

level and $\mathrm{G}_{\mathrm{th}}$ genotype

$\mathrm{E}_{\mathrm{ijk}}=$ random error

\section{Results and Discussion}

\section{Effect on Growth Performance Traits}

Results presented in Table 2 showed that the genetic constitution of the NLC and its interaction with dietary protein levels did not significantly $(p>0.05)$ control any growth performance trait studied. However, main effect of dietary protein levels statistically $(\mathrm{p}<0.05)$ affected ADFI, FCR and PER. Birds on HP diet consumed $2.80-3.77 \mathrm{~g}$ less feed than those on LP and MP respectively. Though the FCR obtained for birds fed LP diet compared with those fed HP, their PER was better than those on HP and MP diets. Studies carried out on Ethiopian local chicken by Tadelle et al. (2003) and Kenyan local chicken by Kingori et al. (2007) under improved environmental (nutrition and management) conditions, growth performance of the local chickens improved remarkably.

Table 2: Growth performance traits of Nigerian local chicken fed different dietary protein levels

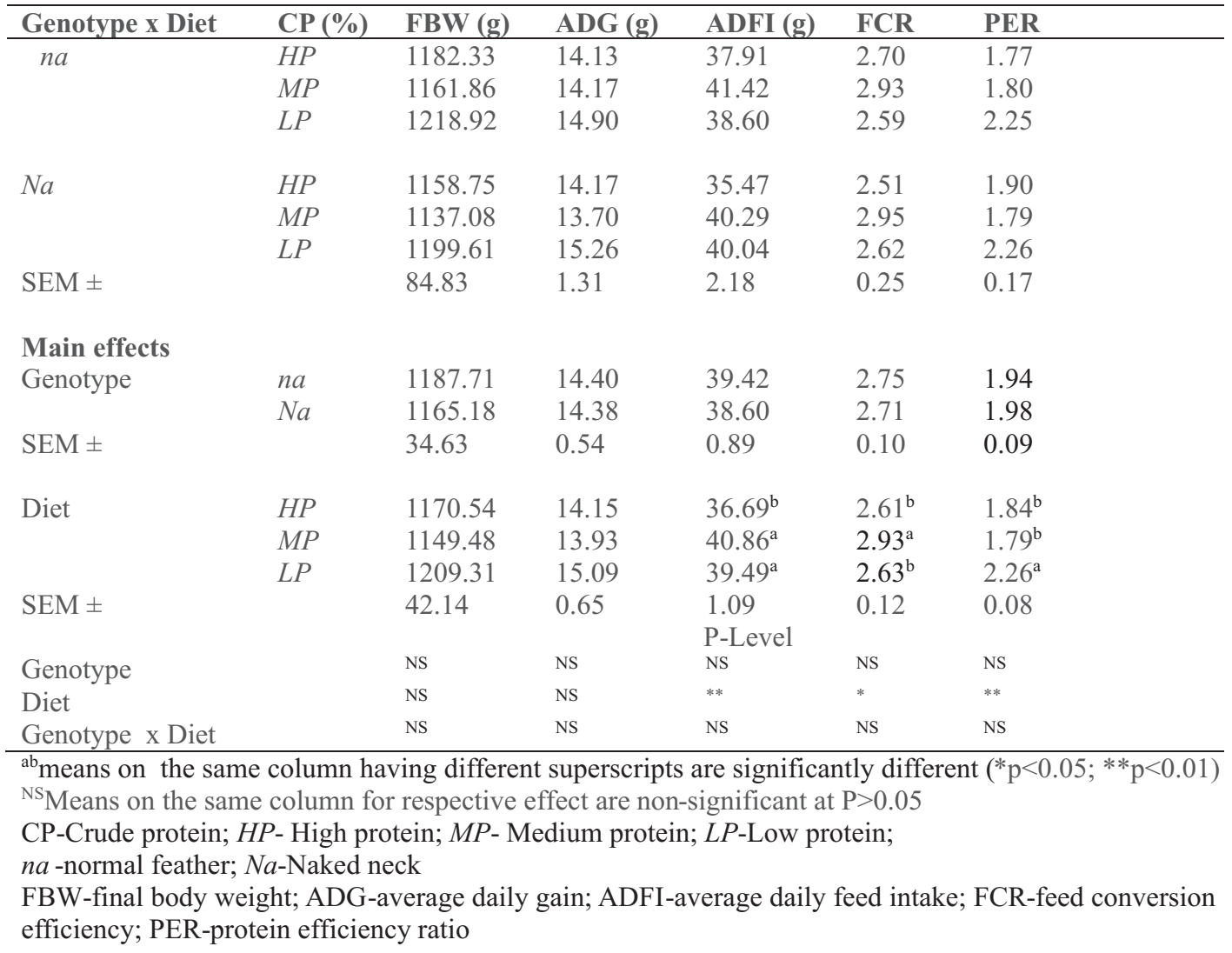




\section{Oleforuh-Okoleh, Nte and Onyegbule}

Although, Isika et al. (2006) observed that the performance of Nigerian local chicken was not influenced by dietary manipulations between 0-12 weeks of age, the present findings do not contend to that since dietary protein levels influenced some performance traits. The performance of birds on LP as observed is in line with the findings of Liu et al.(2015) who reported better performance in daily weight gain and feed: gain ratio (FCR) in Lueyang blackboned chicken populations fed $18 \% \mathrm{CP}$ than those on $20 \%$ CP. The effects of dietary crude protein levels on growth performance traits as presented in this study refutes the findings of Kermanshahi et al. (2011) who reported that broiler birds on $20.80 \% \mathrm{CP}$ performed better than those on $23.97 \% \mathrm{CP}$ and $17.70 \% \mathrm{CP}$ in body weight gain, feed intake and feed conversion ratio. Ndegwa et al. (2001) reported that ad libitum feeding of higher protein diets resulted in better growth rate in Kenyan indigenous chickens at early growth stage however this advantage was later lost during the growing stage when diets with $17-23 \% \mathrm{CP}$ were fed. Nguyen et al.(2010) found that Betong chicks fed dietary protein levels of 17, 19 and $21 \% \mathrm{CP}$ between $42-84$ days of age did not differ in feed:gain and protein:gain ratio though Nguyen and Bunchasak (2005) reported that the Betong chicks on $17 \% \mathrm{CP}$ had smaller weight gain and poorer FCR than those that received 19, 21 and $23 \% \mathrm{CP}$ during early growth stage. Similarly, Buyse et al. (1992) found that decreasing the crude protein content of isoenergetic diets resulted in depressed body weight gain and reduced feed efficiency. Our findings contradict that of Hosseni-Vashan et al. (2010) who observed a decreased PER in relation to lowering the crude protein content of the diet in broiler chickens.

The variation in the various studies could be attributed to varied factors including breed/strain, sex, age, management and environmental conditions (Magala et al., 2012; Kingori et al., 2003; Najib and AlAqil, 2015). The birds used for the present study were improved Nigerian local chickens that had undergone some generations of selection but have not been genetically classified either as meat or layer type chickens. The birds were reared under intensive management system which could have influenced their performance.

Effect on Haematological Traits

Table 3 shows the results of the genotype and dietary protein levels on the haematological traits studied. Packed cell volume (PCV) and platelets were different for the normal-feathered ( $n a$ ) and the naked neck $(N a)$ birds. The $N a$ had higher PCV and platelets concentrations than the na (a variation of $4.55 \pm 1.36 \%$ and $17.5 \pm 5.35 \times 10^{3} \mathrm{~L}^{-1}$ respectively). There were changes in $\mathrm{Hb}$ concentrations, $\mathrm{RBC}, \mathrm{MCHC}$ and platelets when birds were fed different dietary protein levels. These measures were higher for birds on the LP diet than for birds on the HP diet $(\mathrm{P}<0.05)$. Much genotype $\mathrm{x}$ diet interaction was observed with the $\mathrm{Na}$ on HP having the highest PCV while $n a$ birds on LP diet had the highest $\mathrm{Hb}$ concentration, RBC and platelet counts $(\mathrm{p}<0.05)$.

The WBC count was not affected by genotype, dietary protein levels or interaction of genotype and diet. Variations in the haematological status of birds have been traced to their genetic constitution (Islam et al., 2004; Peters et al., 2011; Mohamed et al., 2012).

The haematological values obtained in this study vary from those reported by Pampori and Iqbal (2007) and Elagib and Ahmed (2011) for native chickens of Kashmir and indigenous chickens of Sudan respectively. The PCV concentrations of the two experimental birds affirms the findings of Ladokun et al. (2008) who observed higher 
Nigerian local chicken and dietary protein levels

Table 3: Haematological traits of Nigerian local chickens as influenced by genotype, dietary protein and their interaction

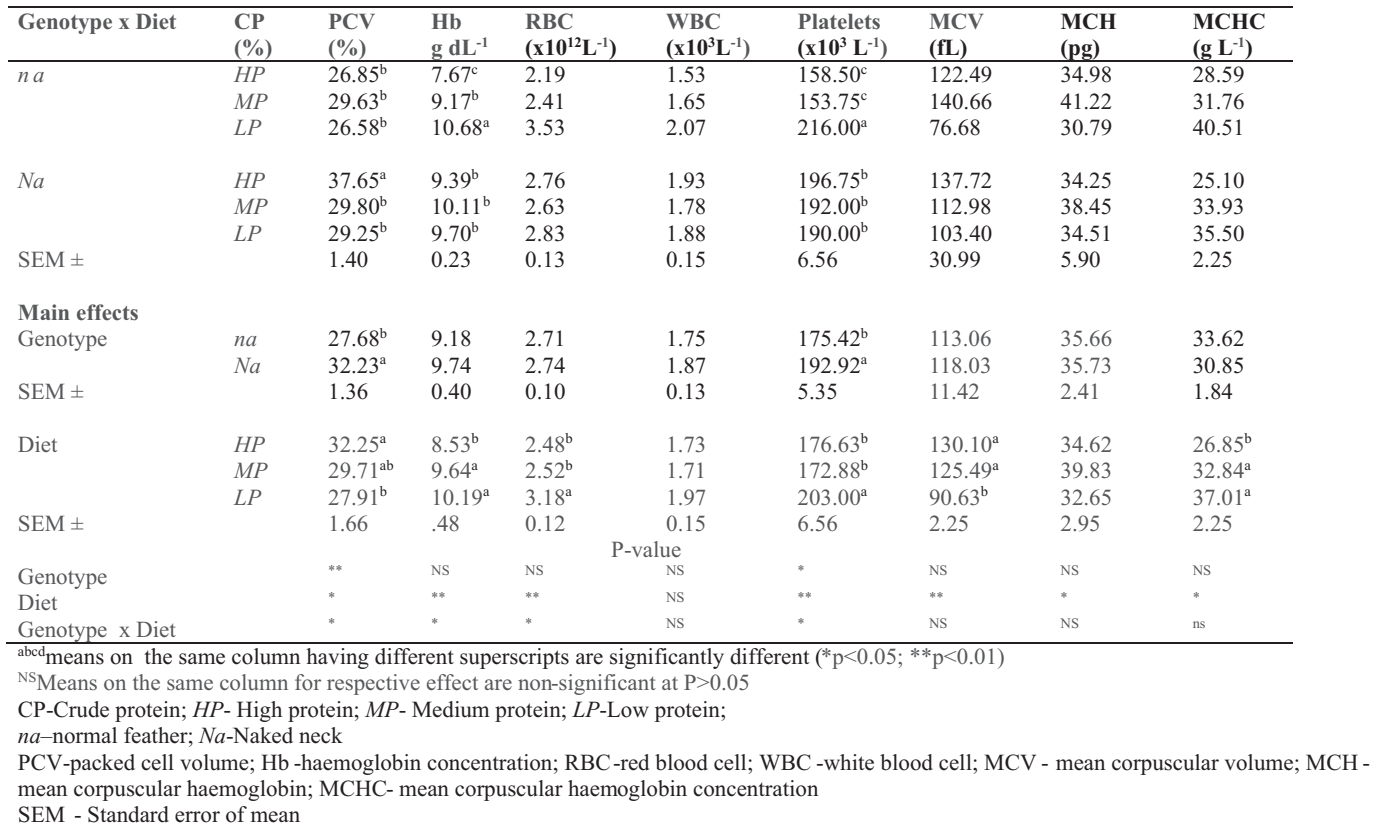

PCV values in the $\mathrm{Na}$ compared to the $\mathrm{na}$. It has been reported that increased PCV indicates better transportation of oxygen and hence, absorbed nutrients (Isaac et al., 2013). There seems to however be a modification to this statement from the present study because birds on HP which had the highest PCV concentrations had similar FCR with those on LP. The volume of the red blood cells in an individual is important because the RBC is involved in the transport of oxygen and carbondioxide in the body since they carry the haemoglobin which reacts with oxygen in the blood to form oxyhaemoglobin during respiration. Soetan et al. (2013) posited that a reduction in the red blood cell count would influence the circulatory/respiratory process by decreasing the volume of oxygen carried to the tissues as well as that of carbondioxide returned to the lungs.

Adamu et al. (2006) worked with albino rats and observed that the diets fed influenced the packed cell volume (PCV), haemoglobin $(\mathrm{Hb})$ and red blood cell (RBC) counts of the rats. Some studies did not observe any variation in some haematological indices of birds due to different dietary protein/amino acid levels (Kermanshahi et al., 2011; Adeyemo et al., 2010). The WBC plays a key role in defending an individual against various pathogenic agents. George-Gay and Parker (2003) noted that decreased WBC count results when there is a decrease in their production in the bone marrow or an increase in their destruction due to viral infections or toxic reactions. None of the factors evaluated in the present study significantly affected the WBC counts. This implies that the immune system of the birds was not compromised by either reducing or increasing the protein levels of the diet. Though it has been posited that high dietary contents could result in low values of haematological indices (Bawala et al., 2007), the results of the present findings indicate that the value of all the 


\section{Oleforuh-Okoleh, Nte and Onyegbule}

haematological traits studied fall within the normal/reference range for domestic fowls as reported by Gullard and Hawkey (1990) and Teare (2006). When haematological values are within the reference range reported for an animal, it implies that the treatment given did not have any adverse effect(s) on the animal during the course of treatment (Togun et al., 2007).

From this study, we can surmise that the observed differences in some of the growth performance traits studied were due to variations in the dietary protein levels given to the birds and had no interference by the genotype of the local chicken nor any interactive effect of genotype and dietary protein levels. The dietary treatments influenced the haematological values of the chickens but not in any adverse way since the values obtained were within the reference range for chickens. Based on the premise that the higher the protein content of a diet, the more expensive it would be, we would suggest that to minimise cost and optimise profit, it would be necessary to raise the Nigerian local chickens on LP diets (18\% and $16 \%$ chick mash and grower mash respectively) as employed in the present study.

\section{Acknowledgements}

The authors appreciate Prof. J. M. Olomu for formulating the diets used for the study. We acknowledge Romanus Kurutsi, and Believe Etche who assisted in data collection. We are grateful to the Teaching and Research Farm of RSUST, Port Harcourt, for granting us permission to use its facilities.

\section{References}

Adamu, S., Thomas, A., Iseh, N. M., Fatihumi, M. Y. and Esieno, K. A. N. 2006. Normal values of haematology of Nigeria adopted albino rats (Rattus norvegicus) in Zaria. Proceedings of the $31^{\text {st }}$ Annual Conference of Nigerian Society for Animal Production.

Adebambo, O. A. 2005. Local poultry breeds genetic improvement for meat and eggs. Proceedings of the $1^{\text {st }}$ International Poultry Summit, Feb. 20-25, Ota, Ogun State, pp: 18.

Adeyemo, G. O., Ologhobo, A. D. and Adebiyi, O. A. 2010. The effect of graded levels of dietary methionine on the haematology and serum biochemistry of broilers. Int. J. of Poult. Sci. 9158-161.

AOAC. 2010. Official Method of Analysis (20th Ed.). Association of Official Analytical Chemistry. Washington DC, USA.

Bawala, T. O., Akpan, U., Ogunnowo, A. O., Fasae, O. A. and Sogunle, O. M. 2007.Influence of dietary magnesium supplementation on the haematological profile of young West African dwarf goats. Proceedings of the $32^{\text {nd }}$ Conference of the Nigerian Society for Animal Production, $18^{\text {th }}-21^{\text {st }}$ March, 2007, Univ. of Calabar, Nigeria. pp.76-78.

Bull, B. S. and Hay, K. L. 2001.Is the Packed Cell Volume (PCV) Reliable? Laboratory Hematology 7:191-196.

Buyse, J., Decuypere, E., Berghan, L., Kuhn, E. R. and Vandesande, F. 1992. Effect of dietary content on episodic growth hormone secretion and heat production of male broiler chickens. Br. Poult. Sci., 33:11011109. DOI:10.1080/0007166 9208417552.

Chemjor, W. 1998. Energy and protein requirements of indigenous 
chickens of Kenya. MSc thesis, Egerton University, Kenya, pp. 83.

Elagib, H.A.A. and Ahmed, A. D.A. 2011. Comparative study on haematological values of blood of indigenous chickens in Sudan. Asian Journal of Poultry Science, 5: 41-45.DOI:10.3923/ajpsaj. 2011.41.45

Feldman, B. F., Zinkl, J. G. and Jain, N. C. 2000. Schalm's Veterinary Hematology. $5^{\text {th }}$ Ed. Ames, IA: Blackwell Publishing Limited.

George-Gay, B. and Parker, K. 2003. Understanding the complete blood count with differential. $J$. Peri-Anesthesia Nursing 18:96117.

Gulland, F. M. D. and Hawkey, C. M. 1990. Avian haematology. Vet Annu 30:126-136.

Harper, A. E. and Rogers, Q. R. 1965. Amino acid imbalance. Proc. Nutr. Soc. 24, 173-190.

Havenstein, G. B., Ferket, P. R., Scheidler, S. E. and Larson, B. T. 1994. Growth, livability, and feed conversion of 1991 vs 1957 broilers when fed "typical" 1957 and 1991 broiler diets. Poult, Sci. 73:1785-1794. PMID:7877934

Hosseini-Vashan, S. J., Jafari-Sayadi, A. R., Golian, A., Motaghinia, Gh., Namvari, M. and Hamedi, M. 2010. Comparison of growth performance and carcass characteristics of broiler chickens fed diets with various energy and constant energy to protein ratio. Journal of Animal and Veterinary Advances 9:2565-2570.

Isaac, L. J., Abah, G., Akpan, B. and Ek a t t e, I. U . 2013 . Haematological properties of different breeds and sexes of rabbits. Proceedings of the 18th Annual Conference of Animal Science Assoc. of Nigeria. 24-27.

Isika, M. A., Okon, B. I., Agiang, E. A. and Oluyemi, J. A. 2006. Dietary energy and crude protein requirement for chicks of Nigeria local fowl and crossbreeds. Int. J. Poult. Sci., 5: 271-274.

Islam, M. S., Lucky, N. S., Islam, M. R., Ahad, A. and Das, B. R. 2004. Haematological parameter of fayoumi, assil and local chicken reared in Sylhet region in Bangladesh. Int. J. Poult. Sci., 3: 144-147.

Kermanshahi, H., Ziaei, N., and Pilevar, M. 2011. Effect of dietary crude protein fluctuation on performance, blood parameters and nutrients retention in broiler chicken during starter period. Global Veterinaria 6: 162-167.

Kingori, A. M., Tuitoek, J. K., Muiruri, H. K. and Wachira, A. M. 2003. Protein requirements of growing indigenous chickens during the 1421 weeks growing period. South Africa. J. Anim. Sci., 33: 78-82.

Kingori, A. M., Tuitoek, J. K., Muiruri, H. K. and Wachira, A. M . 2007. Protein intake of growing local chickens on free-range and their response to supplementation. Int. J. Poult. Sci., 6:617-621.

Ladokun, A. O., Yakubu, A., Otite, J. R., Omeje, J. N., Sokunbi, O. A. and Onyeji, E. 2008. Haematological and serum biochemical indices of $n$ a $k$ e d n e c $k \quad a n d$ normallyfeathered Nigerian indigenous chickens in a sub humid tropical environment. Int. J. Poult. Sci. 7: 55-58.

Liu, S. K., Niu, Z. Y., Min, Y. N., Wang, Z. 
P., Zhang, J., He, Z. F., Li, H. L., Sun, T. T. and Liu, F. Z. 2015. Effects of dietary crude protein on the growthperformance, carcass $\mathrm{characteristics}$ a nd serumbiochemical indexes of lueyang black-bonedchickens from seven to twelve weeks of age. Brazilian J. of Poult. Sci., 17: 103-108.

Magala, H., Kugonza, D. R., Kwizera, H. and Ky a r is i i ma, C.C. 2012.Influence of varying dietary energy and protein on growthand carcass characteristics of Ugandan local chickens. J. Anim. Prod. Adv. 2:316-324.

Mohamed, E. A. A., Ali, O. H. A., Malik, H. E. E. and Yousif, I. A. 2012. Effect of season and dietary protein level on some haematological parameters and blood biochemical compositions of three broiler strains. Int. J. Poult. Sci. 11: 787793.

Mugga, R. 2007. Uganda sees a market for local birds. World Poult., 23:1. http://www.worldpoultry.net.

Najib, H. and Al-Aqil, A. 2015. Effect of se a sonal changes in environmental temperatures on blood parameters of local, necked neck and white leghorn layers. Int. J. Poult. Sci. 14:398402.

National Research Council. 1994. Nutrient requirements of poultry. 9th Revised Edition. National Academy Press, Washington, DC.

Ndegwa, J. M., Mead, R., Norrish, P., Kimani, C. W. and Wachira, A. M. 2001. The growth performance of indigenous Kenyan chickens fed diets containing different protein levels during rearing. Trop. Anim.
Health Prod. 33: 441-448.

DOI:10.1023/A:1010552008639

Ndofor-Foleng, H. M., Oleforuh-Okoleh, V., Musongong, G. A., Ohageni, J., and Duru, U. E. 2015. Evaluation of growth and reproductive traits of Nigerian local chicken and exotic chicken. Indian J. Anim. Res., 49: 155-160. D O I : $10.5958 / 0976$ 0555.2015.00046.1.

Neto, M. G, Pesti, G. M. and Bakalli, R. I. 2000. Influence of dietary protein level on the broiler chicken's response to methionine and betaine supplements. Poult. Sci.79: 14781484.

Nguyen, T. V. and Bunchasak, C. 2005. Effects of dietary protein and energy on growth performance and carcass characteristics of Betong chicken at early growth stage. Songklanakarin Journal Sci. Tech. 27:1771-1178. http://www.oalib.com/references/ $\underline{19300865}$

Nguyen, T. V., Bunchasak, C. and Chantsavang, S. 2010. Effects of dietary protein and energy on growth performance and carcass characteristics of Betong chicken (Gallus domesticus) during growing period. Int. J. Poult. Sci. 9:468-472.

Nwosu, C. C. and Omeje, S. I. 1985. Short-term egg production parameters of the local chicken and its F1 crosses with gold-link under different housing types. East African Agric. and Forestry J. 51: 49-53.

Nwosu, C. C. 1979. Characterization of the local chicken in Nigeria and its potential for eggand $\mathrm{m}$ e a t production. Proceedings of the $1^{\text {st }}$ 


\section{Nigerian local chicken and dietary protein levels}

National Seminar on Poultry Production, Dec.11-13, Ahmadu Bello University, Zaria. pp:187210

Olabanji, R. O., Tarinu, G. O., Akinlade, J. A. and Ojebiyi, O. O. 2007. Growth performanceand haematological characteristics of weaner rabbits fed different levels

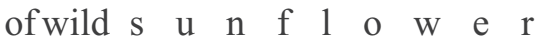
(Tithoniadiversifolia Hems L A Gray) leaf blood meal mixture. Proceedings of 32th Annual Conference of Nigerian Society for Animal Production. pp:207-209.

Oleforuh-Okoleh, V. U., Nwosu, C. C., Adeolu, A. A., Udeh, I., Uberu, C. P. N. and Ndofor-Foleng, H. M. 2012. Egg production performance in a Nigerian local chicken ecotype subjected to selection. Journal of Agricultural Science. 4: 180-186.

Oleforuh-Okoleh, V. U. 2013. Genetic gains from within-breed selection for egg production traits in a Nigerian local chicken. J. Agric. and Biol. Sci. 8:788-792.

Pampori, Z. A. and Iqbal, S. 2007. Haematology, serum chemistry and electrocardiographic evaluation in native chicken of Kashmir. Int. J. of Poult. Sci. 6: 578-582.

Peters, S. O., Gunn, H. H., Imumorin, I. G., Agaviezor, B. O. and Ikeobi, C. O. N. 2011. Haematological studies on frizzled and naked neck genotypes of Nigerian native chickens. Trop. Anim. Health Prod. 4 3: $\quad 631-638$. DOI:10.1007/s11250-010-9743-7.

Soetan, K. O., Akininde, A. S. and Ajibade, T. O. 2013. Preliminary studies on the haematological parameters of cockerels fed raw and processed guinea corn (Sorghum bicolor). Proceedings of 38th Annual Conference of Nigerian Society for Animal Production. 49-52pp..

SPSS Inc. 2010. Statistical procedure for social science. SPSS version 19.0 SPSS Inc., Chicago, IL.

Tadelle, D., Million, T., Alemu, Y. and Peters, K. J. 2003. Village chicken production systems in Ethiopia: 1. Flock characteristics and performance. Livestock Research for Rural Development. 15, Article \# 9

http://www.lrrd.org/lrrd15/1/tadea 151.htm.

Teare, J. A. 2006. Reference ranges for physiological values in captive wildlife. International Species Information System.

Togun, V. A., Farinu, G. O., Oyebiyi, O. O., Akinlade, J. A., Ajibok, H. O. and Olaniyonu, B. L. 2007. Comparative study of the effect of dietary replacement of $15 \%$ maize offal with pigeon pea (Cajanus cajan) grain or leaf meal on performance of weaners rabbits. Proceedings of the $32^{\text {nd }}$ Conference of the Nigerian Society for Animal Production, $18^{\text {th }}-21^{\text {st }}$ March, 2007, Univ. of Calabar, Nigeria. pp:217219.

Udeh. I., Ogbu, C. C., Oleforuh-Okoleh, V. U. 2013. Comparative egg production and mortality of two commercial egg strains, indigenous chicken and their inbred progenies. Journal of Agricultural Science 5: 148-155. DOI:10.5539/jas.v5n9p148.

Uko E. D. and Tamunobereton-Ari, I. 2013. Variability of Climatic Parameters in Port Harcourt, 
Nigeria. Journal of Emerging

Trends in Engineering and Applied

Sciences (JETEAS) 4: 727-730

Wethli, E. and Morris, T. R. 1978. Effects

of age on the tryptophan requirement of laying hens. $B r$. Poult. Sci. 19:559-65.

Received: $15^{\text {th }}$ November, 2016

Accepted: 23 ${ }^{\text {rd }}$ February, 2017 